\title{
Coconut powder and fiber as substrate components for the production seedlings of caatinga species
}

Pó e fibra de coco, como componentes de substratos, para produção de mudas de espécies da caatinga

\author{
D. F. Lima*; M. A. M. Silva \\ Departamento de Ensino/Laboratório de Ecologia Vegetal, Instituto Federal do Ceará, 63902-580, Quixadá-CE, \\ Brasil
}

*ferdiegolima@gmail.com

(Recebido em 12 de agosto de 2020; aceito em 28 de outubro de 2020)

\begin{abstract}
A viable alternative for the final disposal of Cocos nucifera $\mathrm{L}$. waste is its use in the production of substrates to grow seedlings of vegetal species. We carried out an experiment at the Federal Institute of Ceará, Quixadá campus, to assess the technical viability of this alternative. During the experiment, seedlings of Caatinga species (Libidibia ferrea, Cenostigma pyramidale, and Amburana cearenses) were planted in the following treatments: $\mathrm{T} 0-70 \%$ soil $+30 \%$ bovine manure, $\mathrm{T} 1-70 \%$ soil $+20 \%$ bovine manure $+10 \%$ coconut powder, and $\mathrm{T} 2-70 \%$ soil $+20 \%$ bovine manure $+10 \%$ coconut fiber. In each treatment, we used ten seedlings per species, in a completely randomized design. First, we calculated the percentage of emergence, then, monthly, we measured the height and diameter of seedlings. After four months of the experiment, we analyzed the investment in morphometric characteristics. The use of coconut waste favored the emergence percentage of $L$. ferrea and C. pyramidale, but not A. cearenses. The presence of coconut powder provided an increase in maximum height and diameter, primary root length, wood density, and dry matter content in L. ferrea seedlings, and a higher dry matter content in the wood and secondary roots of $C$. pyramidale seedlings. Thus, we concluded that the use of coconut waste, mainly powder, has positive or neutral effects on the growth of $L$. ferrea and $C$. pyramidale seedlings, besides being an environmentally suitable alternative for the final disposal of this material.
\end{abstract}

Keywords: seedling quality, solid waste, reforestation

Uma alternativa viável para destinação final seja o uso de seus resíduos na formulação de substratos para produção de mudas de espécies da caatinga. Para avaliar a viabilidade técnica da alternativa foi realizado um experimento no Instituto Federal do Ceará, campus Quixadá, no qual mudas de Libidibia ferrea, Cenostigma pyramidale e Amburana cearenses foram plantadas nos seguintes tratamentos: $\mathrm{T} 0-70 \%$ solo $+30 \%$ esterco bovino, $\mathrm{T} 1-70 \%$ solo $+20 \%$ esterco bovino $+10 \%$ pó de coco e $\mathrm{T} 2-70 \%$ solo $+20 \%$ esterco bovino + $10 \%$ fibra de coco. Em cada tratamento foram utilizados 10 mudas por espécie, sendo o delineamento experimental inteiramente casualizado. Inicialmente foi calculada a porcentagem de emergência e em seguida, mensalmente, foram medidos altura e diâmetro das mudas. Após quatro meses de experimento foi realizada a análise do investimento em características funcionais. $\mathrm{O}$ uso dos resíduos favoreceu a porcentagem de emergência de $L$. ferrea e C. pyramidale, mas não favoreceu de A. cearenses. A presença do pó de coco proporcionou maior investimento em altura e diâmetro máximos, comprimento da raiz primária, densidade da madeira e teor de matéria seca da madeira em mudas de $L$. ferrea, e de maior teor de matéria seca da madeira e das raízes secundárias em mudas de C. pyramidale. Deste modo, conclui-se que o uso dos resíduos, principalmente o pó, causa efeitos positivos ou neutros na produção de mudas de $L$. ferrea e $C$. pyramidale, além de ser uma alternativa de destinação final ambientalmente adequada para eles.

Palavras-chave: qualidade de mudas, resíduos sólidos, reflorestamento

\section{INTRODUCTION}

The management of sanitation services has been taken into account in environmental performance assessments, especially regarding solid waste, as its improper disposal causes major environmental problems, such as greenhouse gas emissions, bad smell, and contamination of water and soil [1]. The coconut (Cocos nucifera L.) is a crop whose production, processing and consumption network is a waste generator of waste that needs to be discarded. This plant is 
widespread in almost all continents due to its high adaptability, where it is widely cultivated and traded [2], leading to the urgent need for an environmentally appropriate destination of the produced wastes.

Brazil has increased its participation in the world ranking of coconut production, going from the $10^{\text {th }}$ position in the 1990 s [2] to the $5^{\text {th }}$ position in the 2018 [3]. Still in 2018, approximately 2.34 million tons are produced over 216 thousand ha across the country. Besides, Brazil has the highest productivity among producing countries [3]. The third-largest producer state in Brazil, Ceará, is responsible for approximately 186,732 thousand fruits in a cultivated area of 38,965 ha [4]. After consumption, $85 \%$ of the coconut becomes waste, which turns into a serious problem, as the accumulation of this material creates difficulties in health management [5]. In addition, Martins et al. (2016) [6] point out that because coconut shells are organic, they release methane during decomposition when deposited in landfills.

Due to the accumulation of this waste, the scientific community has been searching for alternatives for its use [7]. Bhatnagar et al. (2010) [8] presented the importance of coconut shells in water treatment, through a bibliographic review, in which biosorbents produced from coconut shells showed good potential for removing water pollutants. Freitas, Nogueira and Farinas (2019) [9] assessed the use of coconut shell activated carbon (CSAC) as an alternative adsorbent to improve the efficiency of alcoholic fermentation processes in biorefineries. Their results showed that CSAC increased the process efficiency, proving to be a high capacity and selective adsorbent.

The use of the coconut shell's fiber and powder as an agricultural substrate is another alternative, as they have optimal levels of porosity and absorption, favoring the physiological activity of roots [10]. Many of their properties remain active for long periods [6] due to the high percentage of lignin and cellulose, which, besides providing physical resistance, has resistance to fungi, and acts as a thermal insulator [11]. In addition, the levels of potassium, calcium, and nitrogen present in the coconut shell can contribute to the fertilization of crops [12]. Mattos et al. (2011) [12] also states that the liquid of green coconut shells can be used in the fertilization of crops, as it is a potassium source, and in fertigation, mainly of crops more tolerant to high salinity.

From this perspective, the use of coconut waste has brought good results. Carrijo, Liz and Makishima (2020) [13] and Oliveira et al. (2019) [14] studied coconut fiber and powder, respectively, with superior results in commercial tomato production, reflecting in a ton more commercial fruit in three years of assessment, as well as good results in the tomato root system. Oliveira, Hernandez and Assis Júnior (2008) [15] achieved a better result during the early development of the eggplant, with a substrate made of coconut powder, followed by a commercial non-fertilized substrate (Bioplant).

Besides evaluating the productivity of crops, the number of studies assessing the use of these wastes in the production of forest seedlings has increased in recent years $[16,17,18,19,20]$. Simões, Silva and Silva (2012) [16] obtained better quality of the root system and development of seedlings of Eucalyptus grandis Hill ex Maiden and Eucalyptus urophylla ST Blake using substrates produced with carbonized rice husk and coconut fiber, and vermiculite and coconut fiber, in the proportion 1: 1. Brito et al. (2018) [19] produced better quality Schinopsis brasiliensis Engler seedlings when planted with coconut powder substrate in association with controlled-release fertilizer. Gomes and Freire (2019) [20] stated that coconut powder could be used in the composition of substrates for the growth of Cedrela fissilis L. seedlings, in addition to soil and bovine manure.

However, despite the need to produce seedlings of native species and the problem of accumulation of residues from coconut, it is clear that are few studies with tree species of the caatinga, addressing this issue. Thus, given the need for an appropriate destination for the waste, as well as the knowledge that coconut fibers and powder are good substrate for agricultural and forestry production, this work aimed to evaluate the efficiency of different substrates in quality of seedlings of native species of the caatinga, grown in a nursery. 


\section{METHODS}

\subsection{Experiment design}

The present study was carried out in a plant nursery, with a $50 \%$ U.V. rays retaining cover, located at the Federal Institute of Education, Science, and Technology of Ceará (IFCE), Quixadá Campus. The climate in the region of Quixadá is tropical hot semi-arid, with temperatures ranging from 26 to $28{ }^{\circ} \mathrm{C}$, annual rainfall of $838.1 \mathrm{~mm}$, with rains between February and April, and relative humidity around $65 \%$. The dominant vegetation is the shrubby caatinga [21].

We used $24 \times 18 \mathrm{~cm}$ bags filled with $1 \mathrm{~kg}$ of the substrate to prepare the experiment and sowed three seeds per bag. The substrate was composed of soil, bovine manure, and coconut waste, with different compositions, in three different treatments: T0 (70\% soil $+30 \%$ bovine manure), T1 (70\% soil $+20 \%$ bovine manure $+10 \%$ coconut powder $)$, and $\mathrm{T} 2(70 \%$ soil $+20 \%$ bovine manure $+10 \%$ coconut fiber). The soil used was collected at the Campus and is of the dystrophic red-yellow Argisol type. The coconut fiber and powder were obtained by shredding and grinding of the mesocarp, as described by Carrijo, Liz and Makishima (2020) [13], the fiber was acquired from the Cascais Agroindústria company and the powder from the local agricultural trade. The experimental design was completely randomized, with three treatments and ten repetitions for each treatment, so that 30 seedlings were produced for each species.

In the experiment, we used seeds from the species Cenostigma pyramidale (Tul.) Ganon \& G.P.Lewis (locally known as "Catingueira"), Libidibia ferrea (Mart. ex Tul.) L.P. Queiroz (locally known as "Jucá"), and Amburana cearensis (Allemao) A.C. Sm (locally known as "Cumarú"). We chose these species because they are native to the caatinga, have high importance in the ecosystem, and are widely used in reforestation programs.

\subsection{Collection and data analysis}

During the entire experimental period (four months), we irrigated seedlings daily and measured height and diameter monthly, using a simple measuring tape and a digital caliper, respectively, to assess growth.

During the first measurement, one month after sowing, we counted how many seedlings had emerged in each bag and carried out thinning, keeping one plant per bag. In the last month, we counted how many seedlings survived and measured their maximum height and diameter. The calculation of the relative growth rate in height and diameter followed Benincasa (2003) [22].

After four months, ending the experiment, seedlings were destroyed to collect data on morphometric characteristics above and below the ground. Morphometric analyses followed the protocol proposed by Pérez-Harguindeguy et al. (2013) [23].

We counted the leaves of each seedling and removed six of them, with medium sizes, chosen along the seedling stem. Whenever the plant had a lower number of leaves, we used all available ones. We calculated the leaf area with the image software Image-Pro Plus that expresses the leaf area $\left(\right.$ in $\mathrm{cm}^{2}$ ) scanned while still fresh. We calculated the dry matter content in leaves, which corresponds to the dry weight (g) divided by the water-saturated weight (g), expressed in $\mathrm{g} / \mathrm{g}$, using an analytical scale. First, we weighed leaves still moist to obtain the fresh weight, then, placed the material in the oven at $60{ }^{\circ} \mathrm{C}$ for $72 \mathrm{~h}$ and obtained the dry weight. Next, we divided the leaf area by the dry weight to obtain the specific leaf area.

To study roots, we placed them in a fine-mesh sieve $(0.2 \mathrm{~mm})$ and washed them under running water, until they were free from dirt, which we also removed using a soft brush or fine tweezers. Next, we separated the primary and secondary roots. We used a graduated ruler to determine the vertical length of the primary root, measuring from the surface to where the roots penetrated the soil. We weighed primary and secondary roots, still moist, to obtain the fresh weight (g). After this procedure, we placed both roots in an oven at $60{ }^{\circ} \mathrm{C}$ for $72 \mathrm{~h}$ to obtain the dry weight. The dry 
matter content is the ratio between the dry weight $(\mathrm{mg})$ of roots (primary or secondary) divided by the water-saturated weight (g), expressed in $\mathrm{mg} \cdot \mathrm{g}^{-1}$.

We obtained the density and dry matter content of the wood by collecting a piece of the plant's stem, approximately $3 \mathrm{~cm}$ long. In the laboratory, we weighed fresh samples and immersed them in a container with water for five days to rehydrate until they reached the saturation point necessary for measurement. Next, each piece remained resting outside the container for 5 minutes to drain the excess of water from the saturation. Then, they were measured and immersed in another container with water to determine their volume, based on the displacement of the liquid caused by the immersion of the piece. After that, we placed the pieces in an oven at $60^{\circ} \mathrm{C}$ for $72 \mathrm{~h}$ to obtain the dry weight. Finally, we calculated wood density as the ratio between dry weight and water volume (expressed in $\mathrm{mg} \mathrm{mm}^{-3}$ ) and wood dry matter content as the stem dry weight divided by the watersaturated weight (expressed in $\mathrm{mg} \cdot \mathrm{g}^{-1}$ ).

To analyze the influence of coconut waste on growth and morphometric characteristics of the species, we calculated arithmetic mean for each seedling and each parameter with more than one measurement. The data were submitted to the Shapiro-Wilk normality test. Data with a normal distribution ( $p>0.05$ ) were subjected to an analysis of variance (ANOVA), followed by the ScottKnott test, when ANOVA showed differences between treatments with a significance level of 0.05 . Data without a normal distribution $(\mathrm{p}<0.05)$ were submitted to the Kruskal Wallis test and, when there were significant differences $(\mathrm{p}<0.05)$, the means were compared using the Mann Whitney test.

To determine the relationships between pairs of morphometric characteristics, and the different investments in these characteristics, the values obtained for each seedling were used as points and submitted to correlation analyses, to identify significant ones according to Pearson's coefficient ( $p$ $<0.05)$. Statistical analyses were carried out in the SPSS V25.0 software.

Table 1 shows the list of treatments and characteristics collected in the present study, as well as their units of measurement and abbreviations used in the text.

Table 1: List of abbreviations used in the study and their units of measurement.

\begin{tabular}{llc}
\hline Abbreviations & Name & Unit \\
\hline T0 & 70\% soil + 30\% bovine manure & \\
T1 & 70\% soil + 20\% bovine manure $+10 \%$ coconut powder & \\
T2 & $70 \%$ soil + 20\% bovine manure $+10 \%$ coconut fiber & \\
NuL & Number of Leaves & \\
MHM & Maximum Height Mean & $\mathrm{cm}$ \\
FiH & Final Height & $\mathrm{cm}$ \\
RGH & Relative Growth in Height & $\mathrm{cm} \cdot \mathrm{d}^{-1}$ \\
MDM & Maximum Diameter Mean & $\mathrm{mm}$ \\
FiD & Final Diameter & $\mathrm{mm}$ \\
RGD & Relative Growth in Diameter & $\mathrm{mm} \cdot \mathrm{d}^{-1}$ \\
PRL & Primary Root Length & $\mathrm{cm}$ \\
SLA & Specific Leaf Area & $\mathrm{cm} \cdot \mathrm{g}^{-1}$ \\
LDMC & Leaf Dry Matter Content & $\mathrm{g} \cdot \mathrm{g}^{-1}$ \\
PRDMC & Primary Root Dry Matter Content & $\mathrm{g} \cdot \mathrm{g}^{-1}$ \\
SRDMC & Secondary Root Dry Matter Content & $\mathrm{g} \cdot \mathrm{g}^{-1}$ \\
WDMC & Wood Dry Matter Content & $\mathrm{g} \cdot \mathrm{g}^{-1}$ \\
WD & Wood Density & $\mathrm{g} \cdot \mathrm{cm}^{-3}$ \\
PE & Percentage of Emergence & $\%$ \\
\hline
\end{tabular}

\section{RESULTS}

The percentage of emergence of the seeds sowed in the present study partially corroborated what we expected. The species Libidibia ferrea and Cenostigma pyramidale showed a higher percentage of emergence in the presence of alternative substrate components. All planted seeds (30) of these 
two species emerged in the presence of coconut fiber. The treatment using coconut powder was $83.3 \%$ of emerged seedlings of $C$. pyramidale and $100 \%$ of $L$. ferrea. The presence of coconut waste did not favor the emergence of Amburana cearensis (Allemao) A.C.Sm, which obtained the lowest percentage of emergence, only $10 \%$ for T1 and T2 (Table 2). Due to the low emergence of A. cearensis, it was not possible to obtain growth results and morphometric characteristics for this species.

The presence of coconut powder favored the investment in height and diameter of L. ferrea seedlings. In this treatment, the species showed individuals with higher means of maximum diameters and maximum heights. For $C$. pyramidale, no treatment was statistically superior to the other in these aspects (Table 2).

Table 2: Percentage of emergence, and diameter and height data found for the species Cenostigma pyramidale, Libidibia ferrea and Amburana cearensis in different treatments. Legend: T0 (treatment with $70 \%$ soil $+30 \%$ bovine manure), $T 1$ (treatment with $70 \%$ soil $+20 \%$ bovine manure $+10 \%$ coconut powder), T2 (treatment with $70 \%$ soil $+20 \%$ bovine manure $+10 \%$ coconut fiber), PE (Percentage of Emergence), MDM (Maximum Diameter Mean), RGD (Relative Growth in Diameter), MHM (Maximum Height Mean), and RGH (Relative Growth in Height). Treatments with the same letter showed no significant difference from each other $(p>0.05)$.

\begin{tabular}{lcccccc}
\hline Species & Treatments & PE & MDM & RGD & MHM & RGH \\
Cenostigma & T0 & $33.3^{\mathrm{c}}$ & $3.64^{\mathrm{a}}$ & $0.0099^{\mathrm{a}}$ & $21.6^{\mathrm{a}}$ & $0.0107^{\mathrm{a}}$ \\
pyramidale & T1 & $83.3^{\mathrm{b}}$ & $3.59^{\mathrm{a}}$ & $0.0087^{\mathrm{a}}$ & $23.6^{\mathrm{a}}$ & $0.0067^{\mathrm{a}}$ \\
& T2 & $100^{\mathrm{a}}$ & $3.37^{\mathrm{a}}$ & $0.0101^{\mathrm{a}}$ & $17.0^{\mathrm{a}}$ & $0.0123^{\mathrm{a}}$ \\
\hline \multirow{3}{*}{ Libidibia ferrea } & T0 & $43.3^{\mathrm{b}}$ & $3.69^{\mathrm{b}}$ & $0.0159^{\mathrm{a}}$ & $75.2^{\mathrm{b}}$ & $0.0242^{\mathrm{a}}$ \\
& T1 & $100^{\mathrm{a}}$ & $5.91^{\mathrm{a}}$ & $0.0177^{\mathrm{a}}$ & $103.4^{\mathrm{a}}$ & $0.0197^{\mathrm{b}}$ \\
& T2 & $100^{\mathrm{a}}$ & $4.76^{\mathrm{b}}$ & $0.0173^{\mathrm{a}}$ & $60.6^{\mathrm{c}}$ & $0.0238^{\mathrm{a}}$ \\
\hline \multirow{3}{*}{ Amburana cearensis } & T0 & $60^{\mathrm{a}}$ & - & - & - & - \\
& T1 & $10^{\mathrm{b}}$ & - & - & - & - \\
& T2 & $10^{\mathrm{b}}$ & - & - & - & - \\
\hline
\end{tabular}

When sowed with coconut powder, L. ferrea showed higher wood density $\left(0.742{\mathrm{~g} . \mathrm{cm}^{-3}}^{-3}\right.$, wood dry matter content $\left(0.7291 \mathrm{~g}_{\mathrm{g}} \mathrm{g}^{-1}\right)$, and primary root length $(34 \mathrm{~cm})$. On average, the primary roots of $L$. ferrea seedlings were at least $19 \mathrm{~cm}$ longer in $\mathrm{T} 1 \mathrm{in}$ comparison to other treatments. Coconut powder also favored the development of $C$. pyramidale seedlings, as they showed higher levels of dry matter content in secondary roots $\left(0.4967 \mathrm{~g} \cdot \mathrm{g}^{-1}\right)$ and wood $\left(0.4502 \mathrm{~g} \cdot \mathrm{g}^{-1}\right)$. However, seedlings produced a lower number of leaves in the same treatment. In addition, both species achieved the largest specific leaf areas when planted without coconut waste (Table 3).

Regarding the differential investment in plant organs, we observed that in L. ferrea seedlings planted with coconut fiber (Table 4), taller plants had more leaves, and the largest diameters occurred in plants with higher growth in diameter. When the seedlings were planted with coconut powder (Table 5), diameter and height characteristics were positively related. As the final heights increased, the growth in height, the final diameters, and the growth in diameter also increased. In addition, the more seedlings grew in height, the greater the final diameters and the growth in diameter. However, the characteristics related to the diameter (FiD and RGD) were negatively related to the specific leaf area (SLA). In the control treatment (Table 6), seedlings with higher heights showed more leaves and higher levels of dry matter content in secondary roots. In this treatment, we observed that the number of leaves was negatively related to the amount of dry matter contained in them. The investment in wood (WD and WDMC) and root tissues (PRDMC) was positively related, but, in contrast, there was less investment in SLA and Primary Root Length (PRL).

When sowed with coconut fiber (Table 4), C. pyramidale showed height characteristics (FiH and RGH) positively related to diameter characteristics (FiD and RGD). However, when analyzing other relationships, we noticed that growth was not accompanied by a gain in dry matter, because as the final height increased, there was a reduction in SLA, a pattern also observed in the 
relationships between RGH and WD, FiD and SLA, and FiD and SRDMC. It is worth highlighting that the characteristics indicating investment in tissue quality were positively related (SLA and PRDMC/SRDMC, PRDMC and SRDMC, WD and WDMC). When we used coconut powder as a substrate (Table 5), the C. pyramidale seedlings that showed more leaves also showed higher final heights, PRDMC, WDMC, and WD. Higher heights were accompanied by greater growth in height, but growth resulted in lower SLA. There was a strong positive relationship between the dry matter content in the stem, leaf, and primary root. Without the addition of coconut waste (Table 6), few relationships were observed for $C$. pyramidale. In this treatment, the number of leaves (NuL) was positively related to growth in height, which, in turn, positively affected growth in diameter. Both RGD and NuL showed a conflicting demand with SLA. 
Table 3: Mean of morphometric characteristics found for the species Cenostigma pyramidale and Libidibia ferrea in different treatments. Legend: T0 (treatment with $70 \%$ soil $+30 \%$ bovine manure), $T 1$ (treatment with $70 \%$ soil $+20 \%$ bovine manure $+10 \%$ coconut powder), T2 (treatment with $70 \%$ soil $+20 \%$ bovine manure $+10 \%$ coconut fiber), NuL (Number of Leaves), LDMC (Leaf Dry Matter Content), SLA (Specific Leaf Area), PRL (Primary Root Length), PRDMC (Primary Root Dry Matter Content), SRDMC (Secondary Root Dry Matter Content), WD (Wood Density), and WDMC (Wood Dry Matter Content). Treatments with the same letter showed no significant difference from each other $(p>0.05)$.

\begin{tabular}{|c|c|c|c|c|c|c|c|c|c|}
\hline Species & Treatments & $\mathrm{NuL}$ & LDMC & SLA & PRL & PRDMC & SRDMC & WD & WDMC \\
\hline \multirow{3}{*}{ Cenostigma pyramidale } & T0 & $5.3^{\mathrm{a}}$ & $0.2649^{\mathrm{a}}$ & $569.9^{a}$ & $12.8^{\mathrm{a}}$ & $0.4018^{\mathrm{a}}$ & $0.1987^{b}$ & $0.558^{\mathrm{a}}$ & $0.3628^{b}$ \\
\hline & $\mathrm{T} 1$ & $3.0^{\mathrm{b}}$ & $0.2930^{\mathrm{a}}$ & $350.1^{\mathrm{b}}$ & $22.6^{\mathrm{a}}$ & $0.5412^{\mathrm{a}}$ & $0.4967^{\mathrm{a}}$ & $0.560^{\mathrm{a}}$ & $0.4502^{\mathrm{a}}$ \\
\hline & $\mathrm{T} 2$ & $6.6^{\mathrm{a}}$ & $0.3838^{\mathrm{a}}$ & $55.1^{\mathrm{c}}$ & $19.8^{\mathrm{a}}$ & $0.4726^{\mathrm{a}}$ & $0.2834^{\mathrm{b}}$ & $0.555^{\mathrm{a}}$ & $0.5387^{\mathrm{a}}$ \\
\hline \multirow{3}{*}{ Libidibia ferrea } & T0 & $18.8^{\mathrm{a}}$ & $0.3130^{\mathrm{a}}$ & $255.9^{\mathrm{a}}$ & $16.4^{\mathrm{b}}$ & $0.3653^{\mathrm{a}}$ & $0.2613^{\mathrm{a}}$ & $0.617^{\mathrm{b}}$ & $0.5313^{b}$ \\
\hline & $\mathrm{T} 1$ & $18.4^{\mathrm{a}}$ & $0.4518^{a}$ & $48.3^{\mathrm{b}}$ & $34.0^{\mathrm{a}}$ & $0.4854^{\mathrm{a}}$ & $0.3734^{\mathrm{a}}$ & $0.742^{\mathrm{a}}$ & $0.7291^{\mathrm{a}}$ \\
\hline & $\mathrm{T} 2$ & $17.2^{\mathrm{a}}$ & $0.4528^{a}$ & $183.6^{\mathrm{a}}$ & $15.5^{b}$ & $0.4950^{\mathrm{a}}$ & $0.3617^{\mathrm{a}}$ & $0.626^{\mathrm{b}}$ & $0.5840^{\mathrm{b}}$ \\
\hline
\end{tabular}

Table 4: Correlations of morphometric characteristics of the T2 treatment. Lower diagonal data refer to Libidibia ferrea, and upper diagonal data refer to Cenostigma pyramidale. Legend: T2 (treatment with $70 \%$ soil $+20 \%$ bovine manure $+10 \%$ coconut fiber), NuL (Number of Leaves), FiH (Final Height), RGH (Relative Growth in Height), FiD (Final Diameter), RGD (Relative Growth in Diameter), PRL (Primary Root Length), SLA (Specific Leaf Area), LDMC (Leaf Dry Matter Content); PRDMC (Primary Root Dry Matter Content), SRDMC (Secondary Root Dry Matter Content), WDMC (Wood Dry Matter Content), and WD (Wood Density). When there was a correlation between characteristics ( $p<0.05)$, the value was marked in bold.

\begin{tabular}{lcccccccccccc}
\hline & NuL & FiH & RGH & FiD & RGD & PRL & SLA & LDMC & PRDMC & SRDMC & WDMC & WD \\
\hline NuL & 1 & 0.1619 & 0.2372 & 0.5752 & 0.4058 & 0.3829 & -0.5146 & -0.1802 & -0.5623 & -0.4792 & -0.0564 & -0.4452 \\
FiH & $\mathbf{0 . 7 4 0 2}$ & 1 & $\mathbf{0 . 7 6 2 3}$ & $\mathbf{0 . 6 7 5 8}$ & 0.3159 & 0.0504 & $\mathbf{- 0 . 7 1 0 4}$ & 0.3959 & -0.2608 & -0.5646 & 0.1531 & -0.3312 \\
RGH & 0.4925 & 0.5394 & 1 & $\mathbf{0 . 7 5 7 6}$ & $\mathbf{0 . 8 0 2 9}$ & -0.1451 & -0.4903 & 0.0035 & -0.2224 & -0.3644 & -0.2339 & $\mathbf{- 0 . 6 3 2 9}$ \\
FiD & 0.2517 & 0.3539 & 0.0389 & 1 & $\mathbf{0 . 7 0 0 7}$ & -0.0779 & $\mathbf{- 0 . 8 6 2 2}$ & -0.0511 & -0.5853 & $\mathbf{- 0 . 7 5 3 9}$ & 0.2530 & -0.3486 \\
RGD & 0.3272 & 0.5049 & 0.4538 & $\mathbf{0 . 6 8 3 7}$ & 1 & -0.3384 & -0.3749 & -0.3493 & -0.2779 & -0.3389 & -0.3267 & $\mathbf{- 0 . 7 0 1 5}$ \\
PRL & -0.3799 & -0.4165 & -0.4756 & 0.4687 & -0.0759 & 1 & -0.0448 & 0.4014 & -0.2870 & -0.0212 & -0.1775 & -0.1579 \\
SLA & -0.1482 & 0.2014 & 0.1861 & -0.5953 & -0.2422 & -0.5679 & 1 & -0.2690 & $\mathbf{0 . 6 8 4 2}$ & $\mathbf{0 . 9 3 4 2}$ & -0.5024 & 0.1882 \\
LDMC & 0.1385 & -0.4584 & 0.0003 & -0.1494 & -0.1358 & -0.0171 & -0.6164 & 1 & -0.3606 & -0.1585 & 0.2748 & 0.0669 \\
PRDMC & 0.2559 & 0.4362 & -0.0388 & -0.2348 & -0.30765 & -0.5273 & 0.2934 & -0.1563 & 1 & $\mathbf{0 . 6 5 7 1}$ & -0.4439 & 0.0709 \\
SRDMC & -0.0899 & -0.0679 & 0.2653 & -0.0443 & 0.29149 & 0.0699 & 0.2899 & -0.1893 & $\mathbf{- 0 . 7 0 8 9}$ & 1 & -0.505 & 0.1568 \\
WDMC & 0.2195 & 0.1937 & -0.3196 & 0.4599 & 0.27534 & 0.0052 & 0.0016 & -0.2456 & -0.0237 & 0.1416 & 1 & $\mathbf{0 . 7 3 8 1}$ \\
WD & 0.2182 & 0.3251 & 0.2879 & -0.0061 & 0.11419 & -0.2906 & 0.3492 & -0.3143 & -0.0725 & 0.2799 & 0.1893 & 1 \\
\hline
\end{tabular}


Table 5: Correlations of morphometric characteristics of the T1 treatment. Lower diagonal data refer to Libidibia ferrea, and upper diagonal data refer to Cenostigma pyramidale. Legend: T1 (treatment with $70 \%$ soil $+20 \%$ bovine manure $+10 \%$ coconut powder), NuL (Number of Leaves), FiH (Final Height), RGH (Relative Growth in Height), FiD (Final Diameter), RGD (Relative Growth in Diameter), PRL (Primary Root Length), SLA (Specific Leaf Area), LDMC (Leaf Dry Matter Content), PRDMC (Primary Root Dry Matter Content), SRDMC (Secondary Root Dry Matter Content), WDMC (Wood Dry Matter Content), and WD (Wood Density).When there was a correlation between characteristics ( $p<0.05)$, the value was marked in bold.

\begin{tabular}{|c|c|c|c|c|c|c|c|c|c|c|c|c|}
\hline & $\mathrm{NuL}$ & $\mathrm{FiH}$ & $\mathrm{RGH}$ & FiD & RGD & PRL & SLA & LDMC & PRDMC & SRDMC & WDMC & WD \\
\hline $\mathrm{NuL}$ & 1 & 0.7234 & 0.6506 & 0.3638 & 0.0901 & 0.2835 & -0.4341 & 0.6686 & 0.8489 & 0.3353 & 0.8115 & 0.7977 \\
\hline $\mathrm{FiH}$ & 0.5715 & 1 & 0.7582 & 0.5799 & 0.4874 & -0.2797 & -0.5839 & 0.6736 & 0.4814 & -0.1869 & 0.4738 & 0.5369 \\
\hline RGH & 0.2826 & 0.8078 & 1 & 0.6953 & 0.5552 & -0.0058 & -0.8451 & 0.6238 & 0.6319 & 0.3109 & 0.5268 & 0.6879 \\
\hline FiD & 0.4305 & 0.6575 & 0.6853 & 1 & 0.8671 & 0.0165 & -0.5359 & 0.6252 & 0.5644 & 0.1011 & 0.5457 & 0.6379 \\
\hline RGD & 0.3569 & 0.6359 & 0.7912 & 0.9511 & 1 & -0.0593 & -0.5872 & 0.6651 & 0.3268 & -0.1707 & 0.1991 & 0.3724 \\
\hline PRL & 0.3342 & 0.1531 & 0.0214 & 0.4604 & 0.4578 & 1 & -0.1481 & 0.3981 & 0.6397 & 0.6103 & 0.4288 & 0.4267 \\
\hline SLA & -0.1727 & -0.5377 & -0.5066 & -0.7558 & -0.6816 & -0.0008 & 1 & -0.6739 & -0.5211 & -0.0888 & -0.3963 & -0.6172 \\
\hline OLDMC & 0.5425 & 0.2908 & 0.3379 & 0.4582 & 0.4499 & 0.0138 & -0.4483 & 1 & 0.7918 & 0.0628 & 0.5702 & 0.6892 \\
\hline PRDMC & -0.5373 & -0.6094 & -0.2548 & -0.0588 & -0.0734 & -0.3120 & -0.0206 & -0.1592 & 1 & 0.5331 & 0.8737 & 0.9053 \\
\hline SRDMC & -0.5125 & -0.3635 & -0.3416 & -0.5374 & -0.5775 & -0.3230 & 0.4264 & -0.4343 & 0.0590 & 1 & 0.3264 & 0.3309 \\
\hline WDMC & 0.4468 & 0.2598 & -0.0376 & 0.2177 & -0.0009 & 0.0602 & -0.1781 & 0.2005 & -0.2803 & 0.3808 & 1 & 0.9599 \\
\hline WD & 0.4269 & 0.3814 & 0.0867 & 0.3229 & 0.0974 & -0.0064 & -0.3583 & 0.1227 & -0.2471 & 0.2494 & 0.9424 & 1 \\
\hline
\end{tabular}


Table 6: Correlations of morphometric characteristics of the T0 treatment. Lower diagonal data refer to Libidibia ferrea, and upper diagonal data refer to Cenostigma pyramidale. Legend: T0 ( treatment with 70\% soil + 30\% bovine manure), NuL (Number of Leaves), FiH (Final Height), RGH (Relative Growth in Height), FiD (Final Diameter), RGD (Relative Growth in Diameter), PRL (Primary Root Length), SLA (Specific Leaf Area), LDMC (Leaf Dry Matter Content), PRDMC (Primary Root Dry Matter Content), SRDMC (Secondary Root Dry Matter Content), WDMC (Wood Dry Matter Content), and WD (Wood density). When there was a correlation between characteristics $(p<0.05)$ the value was marked in bold.

\begin{tabular}{lccccccccccccc}
\hline & $\mathrm{NuL}$ & $\mathrm{FiH}$ & $\mathrm{RGH}$ & $\mathrm{FiD}$ & RGD & PRL & SLA & LDMC & PRDMC & SRDMC & WDMC & WD \\
\hline NuL & 1 & 0.7300 & $\mathbf{0 . 7 6 9 3}$ & 0.5746 & 0.7519 & -0.7021 & $\mathbf{- 0 . 8 6 8 4}$ & -0.1241 & -0.4949 & -0.0646 & -0.2512 & -0.4999 \\
FiH & $\mathbf{0 . 8 6 0 6}$ & 1 & 0.7515 & 0.2032 & 0.5486 & -0.6396 & -0.6816 & 0.5641 & -0.4213 & -0.4211 & -0.03135 & -0.1703 \\
RGH & 0.1891 & 0.2342 & 1 & 0.3092 & $\mathbf{0 . 9 0 1 5}$ & -0.6249 & -0.7379 & 0.2521 & -0.4221 & -0.2308 & 0.1555 & -0.0799 \\
FiD & -0.0517 & -0.0142 & -0.1539 & 1 & 0.4364 & -0.2943 & -0.2238 & -0.4025 & 0.1303 & 0.0609 & 0.1987 & -0.0978 \\
RGD & 0.0455 & 0.0685 & 0.6656 & 0.3074 & 1 & -0.3449 & $\mathbf{- 0 . 7 7 4 7}$ & -0.0872 & -0.3707 & 0.1917 & -0.0465 & -0.3212 \\
PRL & -0.2756 & 0.0499 & 0.4419 & -0.1795 & 0.4806 & 1 & 0.5378 & -0.2205 & 0.1768 & 0.6928 & -0.2016 & -0.0083 \\
SLA & 0.1844 & 0.2885 & 0.4946 & -0.4362 & 0.5145 & 0.4941 & 1 & 0.0888 & 0.4636 & -0.1245 & 0.4832 & 0.7064 \\
LDMC & $\mathbf{- 0 . 7 5 4 7}$ & -0.6072 & -0.2414 & 0.4670 & 0.2738 & 0.1554 & -0.201 & 1 & -0.0587 & -0.6856 & 0.4079 & 0.5071 \\
PRDMC & 0.3484 & 0.4909 & 0.1005 & 0.5071 & 0.1759 & -0.2698 & -0.2115 & 0.1877 & 1 & -0.1168 & 0.4727 & 0.3376 \\
SRDMC & 0.4313 & $\mathbf{0 . 7 1 9 2}$ & 0.6176 & -0.0262 & 0.5295 & 0.4264 & 0.6620 & -0.1731 & 0.4989 & 1 & -0.6275 & -0.6210 \\
WDMC & 0.3339 & 0.2134 & -0.2467 & 0.5218 & -0.3242 & $\mathbf{- 0 . 7 3 6 7}$ & $\mathbf{- 0 . 7 4 7 3}$ & -0.0528 & 0.6816 & -0.1725 & 1 & $\mathbf{0 . 9 1 5 6}$ \\
WD & 0.1419 & 0.2045 & -0.4209 & 0.5003 & -0.4518 & -0.5877 & $\mathbf{- 0 . 7 4 1 8}$ & 0.1382 & $\mathbf{0 . 7 2 9 7}$ & -0.1121 & $\mathbf{0 . 9 1 1 6}$ & 1 \\
\hline
\end{tabular}




\section{DISCUSSION}

The herein reported high emergence rate of Libidibia ferrea and Cenostigma pyramidale in different substrates is essential to ensure higher production of seedlings for planting. Scalon et al. (2011) [24] assessed different substrates and their effects on L. ferrea seeds, achieving a $60.4 \%$ emergence in the most effective treatment. They attributed the low percentage of emergence to the low amount of organic matter available. Walter et al. (2018) [25] and Araújo, Silva and Ferraz (2018) [26] also studied L. ferrea seeds. In their best treatments, the authors achieved 92 and $91 \%$, respectively, values closer to those found in our study using coconut waste. Dantas et al. (2011) [27] and Ferreira et al. (2014) [28] achieved, 87 and 69\%, respectively, for the emergence of $C$. pyramidale.

It is likely that Amburana cearenses seeds did not emerge well when planted with coconut powder and fiber due to the high porosity of the substrate, which reduced water retention, causing a negative effect on the emergence. The decrease in water potential hinders the germination and growth of seedlings of Amburana cearenses seeds [29, 30]. We suggest carrying out other experiments using the same substrates irrigated with different amounts of water, or with materials (soil and fiber) with finer granulometry to increase water retention.

The higher investment in diameter and height (assessed through the maximum diameter and maximum height means) observed for $L$. ferrea seedlings, when planted with coconut powder, are desirable results for seedlings that will be taken to the field. In reforestation, it is common to aim at a greater soil cover, assessed through diameter and height data, as plants with these attributes can dissipate part of the energy and intensity of rains, reducing the speed of the water flow and, consequently, soil erosion [31,32]. Besides, such plants attract more pollinators and seed dispersers [33, 34], which are essential for successful planting.

Differently from L. ferrea, C. pyramidale seedlings were not favored by adding coconut waste to the substrate, which demonstrates that this material acts differently in species. Alves and Freire (2017) [17] found similar results when assessing the influence of substrates on the production of seedlings of Handroanthus impetiginosus (Mart. ex DC) Mattos. They noticed that the substrate formed by soil, bovine manure, and coconut powder did not significantly influence plant height and diameter. The author also observed that the use of the powder without the addition of another compound produced seedlings with worse quality in comparison to other treatments. Rodrigues et al. (2017) [18] used green coconut fiber in the production of Moringa oleifera Lam and observed that as the proportion of fiber increased and the proportion of organic compounds decreased, the quality of seedlings decreased and they showed symptoms of nutritional deficiency. However, it is worth mentioning that, unlike some studies, the height and diameter of $C$. pyramidale were not affected by adding coconut waste to the substrate.

When analyzing the investment in morphometric characteristics, we noticed that $C$. pyramidale and $L$. ferrea seedlings showed better quality when planted without coconut fiber or powder, achieving larger specific leaf areas. This characteristic is related to the higher acquisition of resources from the environment $[35,36]$. In the field, seedlings with a larger specific leaf area can benefit from being more effective in mitigating the negative impacts of rain [37], as well as having high water content, and carrying out high photosynthesis rates [38].

In the treatments using coconut waste, mainly coconut powder, as an alternative component of the substrate, species showed a strategy for the conservation of the acquired resources, reflected in higher SRDMC and WDMC in $C$. pyramidale, and higher WD and WDMC in $L$ ferrea. This strategy is characterized by a good efficiency in the use of nutrients [36]. According to Song et al. (2019) [36] and Moradi et al. (2017) [39], high phosphorus levels in the soil favor mass gain in the leaves, stem, and roots. This information corroborates our results, as mass gain, reflected in higher dry matter contents, was found when the species were sowed with coconut waste. Therefore, these substrates improve soil use efficiency by seedlings.

The higher wood density of L. ferrea seedlings planted with coconut powder is also a strategy to maintain resources, so that the biomass acquired is invested in a more resistant tissue. Plants with this type of strategy and high wood density are better for areas that undergo periods of drought, due to their higher hydraulic safety in these periods [40], as harder woods are less sensitive to water 
variability and more resistant to embolism [41], an essential ability for seedlings that will be planted in semi-arid regions.

Besides dry matter content and wood density, the use of coconut powder also positively impacted primary root length. According to Heilmeier (2019) [42] and Forte et al. (2015) [43], investments below the ground are crucial to resist droughts, allowing roots to reach deeper soil layers that bear important water reserves.

When evaluating the correlations between the analysed characteristics, some conflicting demands were identified, which appeared with and without the addition of residues. The conflicting demands reflect differences in biomass allocation between the organs of plants, which can be driven by low availability of resources [44]. When adding resources to the environment (provided by the additional waste), there should be less need for the plant to invest in one organ over another. In $L$. ferrea seedlings the conflicting demands occurred in greater quantity when planted without residues. For $C$. pyramidale, the greatest amount of conflicting demands was found when planted with coconut fiber. Thus, differences in biomass allocation made by species may indicate some type of nutritional deficiency of substrate [45].

\section{CONCLUSION}

Our results showed that coconut waste, mainly coconut powder, favored the emergence and development of seedlings of the species Libidibia ferrea and Cenostigma pyramidale. However, we do not indicate coconut waste to produce Amburana cearensis seedlings, as its emergence rate was very low with that substrate.

When sowed with coconut waste added to the substrate, the analyzed species, mainly L. ferrea, emerged more and showed more investments in characteristics that are strategic for the region. Thus, the use of coconut waste has positive or neutral effects on the production of Libidibia ferrea and Cenostigma pyramidale seedlings. Besides, a seedling substrate is a viable and environmentally appropriate alternative for the final disposal of this material.

\section{REFERENCES}

1. Marchi CMDF. Cenário mundial dos resíduos sólidos e o comportamento corporativo brasileiro frente à logística reversa. Perspectivas em Gestão \& Conhecimento. 2011;1(2):118-135.

2. Martins CR, Jesus Junior LA. Evolução da produção de coco no Brasil e o comércio internacional: panorama 2010. Aracaju (SE): Embrapa Tabuleiros Costeiros; 2011. 32 p.

3. Food and Agriculture Organization of the United States. Faostat. [Internet]. Available from: http://www.fao.org/faostat/en/\#home [Acessed 02 Nov 2018].

4. IBGE. Produção Agrícola Municipal. [Internet] Available from: https://sidra.ibge.gov.br/tabela/1613\#resultado [Acessed 02 Nov 2018].

5. Santos AM. Estudo de Compósitos Híbridos Polipropileno / Fibras de Vidro e Coco para Aplicações em Engenharia [dissertation]. Curitiba (PR): Universidade Federal do Paraná; 2006. 90 p.

6. Martins AP, Silva PLR, Watanabe T, Borelli C, Marciano JPP, Sanches RA. O problema do pós-consumo do coco no Brasil: alternativas e sustentabilidade. Sustent Debate. 2016;7:44-57, doi: 10.18472/SustDeb.v7n1.2016.16566

7. Gonçalves MPM, Silva MIO, Grugiki MA, Feliciano ALP, Silva LB. Substratos alternativos na produção de mudas de Harpalyce brasiliana Benth. Oecol Australis. 2019;23(3):464-472, doi: 10.4257/oeco.2019.2303.06

8. Bhatnagar A, Vilar VJP, Botelho CMS, Boaventura RAR. Coconut-based biosorbents for water treatment - a review of the recent literature. Adv Colloid Interface Sci. 2010;160(1-2):1-15, doi: 10.1016/j.cis.2010.06.011

9. Freitas JV, Nogueira FGE, Farinas CS. Coconut shell activated carbon as an alternative adsorbent of inhibitors from lignocellulosic biomass pre treatment. Ind Crops Prod. 2019;137:16-23, doi: 10.1016/j.indcrop.2019.05.018

10. Abad M, Noguera P, Puchades R, Maquieira A, Noguera V. Physico-chemical and chemical properties of some coconut coir dusts for use as a peat substitute for containerized ornamental plants. Biores Technol. 2002;82:241-245, doi: 10.1016/S0960-8524(01)00189-4 
11. Costa CR, Ratti A, Del Curto B. Product development using vegetable fibers. Int J Des Nat Ecodyn. 2014;9:237-244, doi: 10.2495/DNE-V9-N3-237-244

12. Mattos ALA, Rosa MF, Crisóstomo LA, Bezerra FC, Correia D, Veras LGC. Beneficiamento da casca do coco verde. Fortaleza (CE): Embrapa Agroindústria Tropical; 2011. 38 p. Available from: https://www.passeidireto.com/arquivo/38445378/beneficiamento-da-casca-de-coco-verde

13. Carrijo AO, Liz RS, Makishima N. Fibra da casca do coco verde como substrato agrícola. Hortic Bras. 2020;20(4):533-535, doi: 10.1590/S0102-05362002000400003

14. Oliveira MC, Santos JR, Costa DF, Costa GR, Lourenço EJ. Mudas de tomateiro produzidas à base de pó de coco e esterco bovino curtido. Rev Bras Agropec Sustent. 2019;9(3):87-95.

15. Oliveira AB, Hernandez FFF, Assis Júnior RN. Pó de coco verde, uma alternativa de substrato na produção de mudas de berinjela. Rev Ciênc Agron. 2008;39(1):39-44.

16. Simões D, Silva RBG, Silva MR. Composição do substrato sobre o desenvolvimento, qualidade e custo de produção de mudas de Eucalyptus grandis Hill ex Maiden $\times$ Eucalyptus urophylla S. T. Blake. Rev Ci Fl. 2012;22(1):91-100, doi: 10.5902/198050985082

17. Alves FJB, Freire ALO. Crescimento inicial e qualidade de mudas de ipê roxo (Handroanthus impetiginosus (Mart. Ex DC) Mattos) produzidas em diferentes substratos. ACSA. 2017;13(3):195-202.

18. Rodrigues LA, Muniz TA, Samarão SS, Cyrino AE. Qualidade de mudas de Moringa oleifera Lam. cultivadas em substratos com fibra de coco verde e compostos orgânicos. Rev Ceres. 2016;63(4):545552, doi: 10.1590/0034-737X201663040016

19. Brito LPS, Bezerra TT, Nunes BEM, Cavalcante MZB, Siqueira Filho JA. Produção de mudas de Schinopsis brasiliensis Engler sob prévia lavagem do pó de coco e submetidas a doses crescentes de fertilizante de liberação controlada. Ci Fl. 2018;28(3): 1022-1034, doi: 10.5902/1980509833385

20. Gomes ADV, Freire ALO. Crescimento e qualidade de mudas de cedro (Cedrela fissilis L.) em função do substrato e sombreamento. Sci Plena. 2019;15:110203, doi: 10.14808/sci.plena.2019.110203

21. IPECE - Instituto de Pesquisa e Estratégia Econômica do Ceará. Perfil Municipal 2017 - Quixadá. [Internet]. [place unknown]: IPECE; 2018 Jan [accessed 2020 Jun 29]. Available from: https://www.ipece.ce.gov.br/wp-content/uploads/sites/45/2018/09/Quixada_2017.pdf

22. Benincasa MMP. Análise de crescimento de plantas: noções básicas. Jaboticabal: FUNEP; 2003. 42 p.

23. Perez-Harguindeguy N, Diaz S, Garnier E, Lavorel S, Poorter H, Jaureguiberry P, Bret-Harte MS, Cornwell WK, Craine JM, Gurvich DE, Urcelay C, Veneklaas EJ, Reich RB, Poorter L, Wright IJ, Ray P, Enrico L, Pausas JG, Vos AC, Buchmann N, Funes G, Quetier F, Hodgson JG, Thompson K, Morgan HD, Steege H, Van Der Heijden MGA, Sack L, Blonder B, Poschlod P, Vaieretti MV, Conti G, Staver AC, Aquino S, Cornelissen JHC. New handbook for standardised measurement of plant functional traits worldwide. Austr J Bot. 2013;61(3):167-234, doi: 10.1071/BT12225

24. Scalon SPQ, Teodósio TKC, Novelino JO, Kissmann C, Mota LHS. Germinação e crescimento de Caesalpinia ferrea Mart. Ex Tul. em diferentes substratos. Rev Árvore. 2011;35(3):633-639, doi: 10.1590/S0100-67622011000400007

25. Walter LS, Santos CA, Oliveira LS, Silva ECA. Influência de tratamentos pré-germinativos e crescimento inicial de plântulas de Libidibia ferrea. Pesq Fl Bras. 2018;38:1-6, doi: 10.4336/2018.pfb.38e201801684

26. Araújo AV, Silva MAD, Ferraz APF. Superação de dormência de sementes de Libidibia ferrea (Mart. ex Tul.) L. P. Queiroz var. ferrea. Magistra. 2018;29(3/4):298-304.

27. Dantas BF, Lopes AP, Silva FFS, Batista PF, Pires MMML, Aragão CA. Produção de mudas de catingueira-verdadeira (Caesalpinia pyramidalis Tul.) em função de substratos e luminosidades. Científica. 2011;39(1/2):34-43.

28. Ferreira EGBS, Matos VP, Gonçalves EP, Ferreira RLC, Silva RB. Tratamentos pré-germinativos em sementes de duas espécies do gênero Poincianella. Rev Ciênc Agron. 2014;45(3):566-572, doi: 10.1590/S1806-66902014000300018.

29. Guedes RS, Alves EU, Gonçalves EP, Viana JS, França PRC, Lima CR. Umedecimento do substrato e temperatura na germinação e vigor de sementes de Amburana cearensis (All.) A.C. Smith. Rev Bras Sementes. 2010;32(3):116-122, doi: 10.1590/S0101-31222010000300013

30. Almeida JPN, Pinheiro CL, Lessa BFT, Gomes FM, Medeiros Filho S. Estresse hídrico e massa de sementes na germinação e crescimento de plântulas de Amburana cearensis (Allemão) A.C. Smith. Rev Ciênc Agron. 2014;45(4):777-787, doi: 10.1590/S1806-66902014000400016

31. Mekonnen M, Keesstra SD, Ritsema CJ, Stroosnijder L, Baartman JEM. Sediment trapping with indigenous grass species showing differences in plant traits in northwest Ethiopia. Catena. 2016;147:755763, doi: 10.1016/j.catena.2016.08.036

32. Kervroëdan L, Armand R, Saunier M, Ouvry JF, Faucon MP. Plant functional trait effects on runoff to design herbaceous hedges for soil erosion control. Ecol Engr. 2018;118:143-151, doi: 10.1016/j.ecoleng.2018.04.024. 
33. Alencar CAB, Cóser AC, Martins CE, Oliveira RA, Cunha FF, Figueiredo JLA. Altura de capins e cobertura do solo sob adubação nitrogenada, irrigação e pastejo nas estações do ano. Acta Sci. Agron. 2010;32(1):21- 27, doi: 10.4025/actasciagron.v32i1.319

34. Oliveira MC, Ribeiro JF, Passos FB, Aquino FG, Oliveira FF, Sousa SR. Crescimento de espécies nativas em um plantio de recuperação de Cerrado sentido restrito no Distrito Federal, Brasil. Rev Bras Biociênc. 2015;13:25-32.

35. Liu HY, Li Y, Ren F, Lin L, Zhu WY, He JS, Niu KC. Trait-abundance relation in response to nutrient addition in a Tibetan alpine meadow: the importance of species trade-off in resource conservation and acquisition. Ecol Evol. 2017;7:10575-10581, doi: 10.1002/ece3.3439

36. Song G, Wang J, Han T, Wang Q, Ren H, Zhu H, Wen X, Hui D. Changes in plant functional traits and their relationships with environmental factors along an urban-rural gradient in Guangzhou, China. Ecol Indic. 2019;106:105558, doi: 10.1016/j.ecolind.2019.105558.

37. Zhu H, Fu B, Wang S, Zhu L, Zhang L, Jiao L, Wang C. Reducing soil erosion by improving community functional diversity in semi-arid grasslands. J Appl Ecol. 2015;52:1063-1072, doi: 10.1111/13652664.12442

38. Poorter H, Niinemets Ü, Poorter L, Wright IJ, Villar R. Causes and consequences of variation in leaf mass per area (LMA): a meta-analysis. New Phytologist. 2009;182:565-588, doi: 10.1111/j.14698137.2009.02830.x

39. Moradi J, Mudrák O, Kukla J, Vicentini F, Šimáčková H, Frouz J. Variations in soil chemical properties, microbial biomass, and faunal populations as related to plant functional traits, patch types, and successional stages at Sokolov post-mining site - a case study. Eur J Soil Biol. 2017;83:58-64, doi: 10.1016/j.ejsobi.2017.10.001

40. Garnier E, Vile D, Roumet C, Lavorel S, Grigulis K, Navas ML, Loret F. Inter- and intra-specifc trait shifts among sites differing in drought conditions at the north western edge of the Mediterranean Region. Flora. 2018;254:147-160, doi: 10.1016/j.flora.2018.07.009

41. Rowland L, Malhi Y, Silva-Espejo JE, Farfán-Amézquita F, Halladay K, Doughty CE, Meir P, Phillips OL. The sensitivity of wood production to seasonal and interannual variations in climate in a lowland Amazonian rainforest. Oecologia. 2014;174:295- 306, doi: 10.1007/s00442-013-2766-9

42. Heilmeier H. Functional traits explaining plant responses to past and future climate changes. Flora. 2019;254:1-11, doi: 10.1016/j.flora.2019.04.004

43. Fort F, Cruz P, Catrice O, Delbrut A, Luzarreta M, Stroia C, Jouany C. Root functional trait syndromes and plasticity drive the ability of grassland Fabaceae to tolerate water and phosphorus shortage. Environm Exp Bot. 2015;110:62-72, doi: 10.1016/j.envexpbot.2014.09.007

44. Mensah S, Kakaï RG, Seifert T. Patterns of biomass allocation between foliage and woody structure: the effects of tree size and specific functional traits. Ann Forest Res. 2016,59:49-60, doi: https://doi.org/10.15287/afr.2016.458.

45. Sun J, Wang H. Soil nitrogen and carbon determine the trade-off of the above and below-ground biomass across alpine grasslands, Tibetan Plateau. Ecol Indic. 2016;60:1070-1076, doi: 10.1016/j.ecolind.2015.08.038 